\title{
Landowners, Caliphs and State Policy over Landholdings in the Egyptian Countryside
}

\author{
Theory and Practice
}

\author{
Marie Legendre
}

Looking at the evolution of landholding in the first centuries of Islam in Egypt requires historians to make use of documents written in the three different languages employed at that time: Greek, Coptic and Arabic. ${ }^{1}$ Together they form a very large corpus as issues concerning land can appear in fiscal, legal and private documents as well as in accounts of all kinds. Documents in each language are, however, mostly studied in isolation and/or by categories of documents, for obvious reasons of linguistic expertise. Only a small number of scholars have attempted to make use of this corpus in order to study landholding and landowners in the early Islamic period. The latest attempt was made by P. Sijpesteijn when focusing on the administration of the early Islamic countryside and the development of Muslim communities after the conquest. ${ }^{2}$ For the Arabic material specifically, a lot has been done by Gladys Frantz-Murphy, notably with her research on Arabic agricultural leases and tax receipts from the Abbasid to the Fatimid period (eighth-eleventh century), preceded and followed by many articles on the same topic. ${ }^{3}$ However, outside of this corpus of leases and receipts, the many other Arabic documents referring to landholdings have not been looked at systematically. The present article will contribute to this debate. Its aim is to look at the pre-Tulunid period in Egypt and to consider a number of case studies where papyri reveal particularities in early

1 I am deeply grateful to Sobhi Bouderbala, Alain Delattre, Daisy Livingston and Petra Sijpesteijn for their comment and suggestions on earlier versions of this research. I would also like to thank the two anonymous reviewers for their very valuable feedback.

2 Petra M. Sijpesteijn, "Landholding Patterns in Early Islamic Egypt," Journal of Agrarian Change 9, no. 1(2009):120-133; idem, Shaping a Muslim state:The World of a Mid-Eighth-Century Egyptian Official (Oxford: Oxford University Press, 2013), 152-171.

3 Gladys Frantz-Murphy, Arabic Agricultural Leases and Tax Receipts from Egypt, 148-427 A.H./ 765-1035A.D. (Vienna: Hollinek, 2001); idem, "The Economics of State Formation in Early Islamic Egypt," in From al-Andalus to Khurasan:Documents from the Medieval Muslim World, eds. Petra Sijpesteijn et al. (Leiden: Brill, 2007), 101-114. 
Islamic landholdings that are not perceptible in narrative sources. Our focus will be on the involvement of the caliphs, their kinsfolk and the government's attitude towards the management of land within the province of Egypt, especially within the fiscal system. We will look at two types of land property. The first is land personally owned by the caliph and his family and the second is land that appears in the hand of individuals with Muslim names but who are, most of the time, unknown to us as members of the provincial or imperial elite. Our goal will be to reveal at each stage how papyri and literary sources do not necessarily tell the same story but provide diverse points of view on the same events and processes.

\section{$1 \quad$ State of the Art and Objectives}

The chronology covered here stretches between two periods that have benefited from productive research initiatives: the late antique period and the Middle Islamic period. Our understanding of landed property in the early Islamic period is often presented as relying on the state of research on the Late Byzantine context. In Egypt, this topic is still very much influenced by the authoritative work of J. Gascou on the "Grand domaines" based on the Oxyrhynchite corpus of the Flavius Apiones (fifth-early seventh centuries) discussed since by J. Banaji, P. Sarris and T. Hickey. ${ }^{4}$ Gascou identifies three types of owners: imperial, private and the Church. ${ }^{5}$ However, the position of imperial and large private landowning, characteristic of the Late Byzantine chora, is not clear at the time of the Islamic conquest as there is very little evidence for such estates after the Sasanian period (619-629). P. Sijpesteijn has argued that those domains must have been seized by the Sasanian authorities and fragmented between smaller landowners after their retreat, making us question whether Byzantine landholding patterns should so strongly influence our vision of the early Islamic period. ${ }^{6}$ I. Marthot's comparison of the sixth- and eighth-century doc-

4 Jean Gascou, "Les grands domaines, la cité et l' état en Égypte byzantine (recherches d' histoire agraire, fiscale et administrative)," Travaux et Mémoires 9 (1985): 1-9o, repr. Fiscalité et Société en Égypte Byzantine (Paris: Centre de recherche d'histoire et civilisation de Byzance, 2008), 125-213; Jairus Banaji, Agrarian Change in Late Antiquity: Gold, Labour, and Aristocratic Dominance (Oxford: Oxford University Press, 2001 [repr. 2007]); Todd M. Hickey, "Aristocratic Landowning and the Economy of Byzantine Egypt," in Egypt in the Byzantine World 450-700, ed. Roger E. Bagnall (Cambridge: Cambridge University Press, 2007), 288-308.

5 Gascou, "Les grand domaines," 4.

6 Sijpesteijn, "Landholding Patterns," 124. 
uments of Aphrodito has revealed the difficulties in reconstructing landowning during the transition of political authority between Byzantium and Islam. This is certainly explained by the scope of each of the dossiers. The sixth-century documents linked to the poet Dioscorus were for the most part produced locally. They relate to his family and to the administration of the village where he originated from and where the documents were found and they give numerous pieces of information on landed properties in the territory of Aphrodito. ${ }^{7}$ On the other hand, the eighth-century dossier is composed of administrative documents: letters from the governor Qurra b. Sharik (in office 9o/709-96/714) in Fustâat to the local administrator, Basilios, registers of the village and documents written by taxpayers to the administration. Mentions of landowning are found in the registers, but they are scarcer and less detailed than in the sixthcentury corpus. ${ }^{8}$ Moreover, only few connections can be made between the various micro-toponyms associated with those properties between the sixth and eighth-century corpuses, and when this is possible, the documents from each period do not give the same type of information..$^{9}$ As a result these two dossiers of Aphrodito do not provide a critical mass of evidence for continuities or changes in landholding. Finally, numerous other documents contribute to our knowledge of churches and monastic estates in the seventh and eighth century, but these corpora do not cover the late antique period. ${ }^{10}$

As for the Middle Islamic period, in the ninth century, the implementation of the first independent Islamic dynasty in Egypt, the Tulunids $(254 / 868-$ 292/905) coincides with clear attestation of tax-farming in papyri since the conquest, and we will concentrate on landholding prior to that.11 The Fatimid

$7 \quad$ This sixth-century corpus notably comprises a cadaster and fiscal registers that allowed Constantin Zuckerman to reconstruct much of the fiscal system of the time: $\mathrm{Du}$ village à l'Empire: autour du registre fiscal d'Aphroditô (525/526) (Paris: Centre de recherche d'histoire et civilisation de Byzance, 2004).

8 Isabelle Marthot, "Monastic Estates in Transition from Byzantine to Islamic Egypt: Evidence from Aphrodito," (forthcoming).

9 Isabelle Marthot, "Un village égyptien et sa campagne: étude de la microtoponymie du territoire d'Aphrodité (VI ${ }^{\mathrm{e}}-\mathrm{VIII}^{\mathrm{e}} \mathrm{s}$.)" (PhD diss., École Pratique des Hautes Études, Paris, 2013), 184-242.

10 Alain Delattre, Papyrus coptes et grecs du monastère d'apa Apollô de Baouît conservés aux Musées royaux d'Art et d'Histoire de Bruxelles (Bruxelles: Académie royale de Belgique, 2007), 77-79; T. Sebastian Richter, "Cultivation of Monastic Estates in Late Antique and Early Islamic Egypt: Some Evidence from Coptic Land Leases and Related Documents," in Monastic Estates in Late Antique and Early Islamic Egypt: Ostraca, Papyri, and Essays in Memory of Sarah Clackson, eds. Anne Boud'hors, James Clackson, Catherine Louis and Petra M. Sijpesteijn (Cincinnati: American Society of Papyrologists, 2009), 205-215. 
period (359/969-567/1171) also appears with a somehow clearer pattern when looking at forms of Islamic landowning. ${ }^{12}$ A lot of scholarly effort has been concentrated on the introduction of the $i q t \bar{a}^{c}$ in Iraq from the ninth century onwards: a system of land grant according to which members of the armies were remunerated without direct property, a retribution only based on land production. ${ }^{13}$ However, the turbulent history of late Abbasid Egypt and the subsequent implementation of the Fatimid caliphate raise questions on the introduction of the military iqt $t \bar{a}$ in the same period in Egypt. The only study to date on the implementation of such land grants, from the point of view of rural authorities and not of the central government, is the work of J-Cl. Garcin on the Upper Egyptian city of Qūṣ (approximately 700 kilometers south of Cairo) where it starts only under the Ayyubids (567/1173-648/1250). ${ }^{14}$ However, from the Fatimid period on, a new type of literary production spread in Egypt that is not available for the early Islamic period and gives a detailed picture of the land revenues and their use. ${ }^{15}$ These are fiscal treaties, listing the land revenues of each administrative division. The earliest preserved example is the thirteenthcentury register of Egyptian districts written by Ibn Mammātī (d. 606/1209), the dīwān secretary of the first Ayyubid sultans Saladin (r. 564/1169-589/1193) and al-'Azīz (r. 589/1193-595/1198), in which he relies heavily on material from the Fatimid period. ${ }^{16}$

Islamic period in Egypt. However, to the best of my knowledge, there is no evidence supporting this for the Umayyad and Abbasid period: Frede Løkkegaard, Islamic Taxation in the Classic Period, with Special Reference to Circumstances in Iraq (Copenhagen: Branner og Korch, 1950), 106; Petra M. Sijpesteijn, "Profit Following Responsibility: A Leaf from the Records of a Third-Century Tax-Collecting Agent," Journal of Juristic Papyrology 31 (2001): 91-132.

12 Between the end of the Tulunid period (292/905) and the rise of the Fatimids in Egypt (359/969), the return to Abbasid leadership is followed by the rise of a second independent dynasty in Egypt: the Ikhshidids (323/935-358/969). The implications of this short-lived dynasty for landholdings, if any, is far from clear.

13 Claude Cahen, "L'évolution de l'iqtâ du $\mathrm{IX}^{\mathrm{e}}$ au XIII ${ }^{\mathrm{e}}$ siècle: contribution à une histoire comparée des sociétés médiévales," Annales: Économies, Sociétés, Civilisations 8, no. 1 (1953): 25-52; 'Abd al-'Aziz Duri, "The Origins of 'Iqta' in Islam," al-Abhath 22 (1969): 322; Yaacov Lev, State and Society in Fatimid Egypt (Leiden: Brill, 1991), 122-130; Tsugitaka Sato, State and Rural Society in Medieval Islam (Leiden: Brill, 1997), 1-17.

14 Jean-Claude Garcin, Qūṣ: un centre musulman de la Haute-Égypte médiévale (Cairo: Institut Français d' archéologie orientale, 2005), 145-147, 231-286.

15 Beyond literary sources, a great mass of documents is available for the study of the Fatimid countryside outside the Genizah corpus: Jean-Michel Mouton, "Un village copte du Fayyoum au XI ${ }^{\mathrm{e}}$ siècle, d' après la découverte d' un lot d' archives," Comptes rendus de l'Académie des inscriptions et belles-lettres 146, no. 2 (2002): 447-458.

16 Ibn Mammātī, Kitāb Qawānīn al-dawāwì̄n, ed. A.S. Atiya (Cairo: Maktabat Matbūlī, 1943); 
The present contribution will focus instead on Egypt as a province under the authority of the Medinan (21/642-38/659), Umayyad (38/659-132/750) and Abbasid caliphs (132/750-254/868). For areas outside Egypt dominated by these dynasties, literary sources produced for the most part under the Abbasids are often the only substantial body of sources available. ${ }^{17}$ Even for Egypt, ninthtenth century literary accounts are often used to provide a framework in order to understand the information given by seventh-eighth century papyri. The earliest Islamic sources produced in Egypt are represented by a father and son often identified by the same name:Ibn 'Abd al-Hakam: the father (d. 214/829) is known, among other works, for his Biography of 'Umar b. 'Abd al-'Aziz and the $\operatorname{son}(\mathrm{d} .257 / 871)$ for his History of the Conquest of Egypt and North Africa. ${ }^{18}$ Other known works of the pre-Fatimid period are Ibn Yūnus' (d. 347/958) biographical dictionary and al-Kindì's (d. 35\%/969) History of the governors and judges of Egypt. ${ }^{19}$ These authors were all part of the scholarly elite of Fusțāt whose center of interest had very little to do with the organization of rural areas. However, since estates were a current subject of dispute and an asset of control, several mentions of landholdings are found in those texts. However, their aim was not to provide an overview of administrative practices, as their interested lay only in the significance of landholding for the elite they were part of. Egyptian literature produced in the early Islamic period reflects mainly the history of the Delta including Fustạt, the capital of the Islamic province of Egypt, and Alexandria,

Richard S. Cooper, "Land Classification Terminology and the Assessment of the Kharāj Tax in Medieval Egypt," Journal of the Economic and Social History of the Orient 17 (1974): 91-102. The recently published archive of the Banu Bifam, dating from Fatimid times, includes a number of deeds of sales of land and tax receipts that can also contribute to our knowledge of landowning in that period; Christian Gaubert and Jean-Michel Mouton, Hommes et villages du Fayyoum dans la documentation papyrologique arabe (Xe-XIe siècles) (Paris: Droz, 2014). Another relevant work of the Ayyubid period is al-Nābulusīs Ta'rīkh al-Fayyūm, Yossef Rapoport, Rural Economy and Tribal Society in Islamic Egypt: A Study of Al-Nabulusi's 'Villages of the Fayyum' (Turnhout: Brepols, 2018).

17 Cf. in the present volume, the contributions of Harry Munt for Arabia and Michele Campopiano and Peter Verkinderen for Iraq.

18 Ibn 'Abd al-Ḥakam, Sìrat 'Umar b. 'Abd al-'Azizz 'alā mā rawāhu Mālik wa asḥābuhu, end ed., ed. A. 'Ubayd (Cairo: Maktabat Wahba, 1954); Ibn 'Abd al-Hakam, Futūh Miṣr wa$a k h b \bar{a} r u h \bar{a}$, ed. Ch. Torrey (New Haven: Yale University Press, 1922).

19 al-Kindī, Kitāb al-Wulāt wa kitāb al-quḍāt, ed. R. Guest (Leiden: Brill, 1912). Ibn Yūnus' work will be used for numerous references, but he does not, unfortunately, provide data on the properties of the listed individuals: Ibn Yūnus, Tārīkh Ibn Yūnus al-Mișrī, 2 vols., ed. 'A. 'Abd al-Fattāh (Beyrouth: Dar al-Kutub al-ilmiyya, 2000). On pre-Fatimid Egyptian sources, cf. Sobhi Bouderbala, "Ǧund Mișr: étude de l' administration militaire dans l'Égypte des débuts de l'Islam (21/642-218/833)” (PhD diss., Sorbonne University, 2008), 11-69. 
the main center of literary production at the time of the conquest. ${ }^{20}$ On the other hand, papyrus documents are restricted to the Egyptian valley, excluding almost entirely the Delta because of the less favorable conditions of preservation for papyrus. ${ }^{21}$ In that sense the two bodies of sources used in the following lines record the histories of different geographical areas and have a very different focus and purpose. They do not provide the same point of view, so their information is hardly comparable in the strict sense of the term.

\section{The Literary Source Material}

The way the conquest of Egypt took place is presented in Islamic narratives as having implications for the fiscal status of lands and for access to landowning for the conquering elite. Those debates prevail in past and present research, and for that reason, we will start by looking at the literary corpus.

In two different articles K. Morimoto covered the debates of medieval jurists concerning the conquest of Egypt and how, in their view, it defined the settlement pattern of the conquerors, but also the fiscal measures they introduced to the conquered lands. This discourse is not unique to Egyptian sources, as for all regions of the empire Islamic narratives claim that conquest by force ('anwatan) or by treaty (sulhan) implied different treatments of the conquered land. Land conquered by force would be acquired as state land by the conquerors and land conquered by treaty would remain in the hand of the conquered who would then pay the land tax $($ kharaj $j) .{ }^{22}$ Morimoto revealed the disagreements jurists expressed regarding the conquest of Egypt by force or by treaty. Reports given by the different works or even within the work of single authors are contradictory partly because the whole province was not conquered in the same way. ${ }^{23}$ However, one work that Morimoto did not take

20 This remark is equally relevant for literature preserved from a Christian and a Muslim milieu in that period, cf. Johannes den Heijer, "La conquête arabe vue par les historiens coptes," in Valeur et distance: identités et sociétés en Égypte, ed. Christian Décobert (Paris: Maisonneuve et Larose, 2000), 227-245.

21 Herbert Verreth, The Provenance of Egyptian Documents from the eighth Century Bc till the eighth Century AD (Louvain: Trismegistos Online Publications, 2009), 235.

22 Koseï Morimoto, "Land Tenure in Egypt during the Early Islamic Period," Orient 11 (1975): 109-153. Issues discussed in this article and the one quoted below are picked up again in his: The Fiscal Administration of Egypt in the Early Islamic Period (Kyoto: Dohosha, 1981).

23 Koseï Morimoto, "Muslim Controversies Regarding the Arab Conquest of Egypt," Orient 13 (1977): 89-105: looks into the reports of Ibn 'Abd al-Ḥakam (d. 257/871), al-Balādhurī (d. 279/892), al-Ya'qūbī (d. 284/897), al-Ṭabarī (d. 310-923), Euthychius (d. 328-940) and 
into account is that of A. Noth who argued convincingly a few years earlier, that those discussions, whether they concerned Egypt or other conquered provinces, did not arise at the time of the conquest but were raised by jurists only from the end of the seventh or the beginning of the eighth century on. ${ }^{24}$ These issues truly monopolize the jurists' and historians' understanding of the conquest and of the fiscal system applied to the different provinces of the early Islamic Empire in the texts available to us from the ninth century on. As such, they certainly make more sense in explaining the Abbasid, or at best the late Umayyad, context rather than the time of the conquest.

Morimoto also questioned the arguments made in Islamic narratives that the settlement pattern of the conquerors had fiscal implications that had been defined during the conquest of Iraq (16/637). According to that, the caliph Umar I (r. 12/634-24/644) took the former Sassanian Imperial lands as state land $(s a w a \bar{f} f i)$ from which estates were distributed amongst the conquest army. ${ }^{25}$ Those grants made in favor of the conquerors by the caliphs were called qați $a$ (pl. qațāici). ${ }^{26}$ Based on their tax regime, the corresponding lands were called 'ushr land (i.e. 'tithe') as opposed to kharäj-land, land that had remained in the hand of the conquered - as conquered by treaty - and on which a higher land-tax, the kharäj, was imposed. ${ }^{27}$ The payment of kharäj is presented there by jurists as a rent paid on the conquered lands, the income of which should benefit the whole Muslim community. ${ }^{28}$

The balance of those two types of land taxes, kharāj and 'ushr is presented as the reason for great conflict that would have justified a change of fiscal policy by the time the conquest of Egypt started. This change is presented as follows in the narratives: the land conquered after Iraq was not to be divided among the conquest army but left in the hand of its owners and exploited indirectly through taxation. The conquered land of Egypt was then left in the possession

al-Ṣuyūțī (d. 9o6-1505), all from the Abbasid period, from Egypt or Iraq. The re-conquest of Alexandria by force appears to be particularly difficult for them to reconcile with the so-called "treaty of Babylon" in order to decide on the status of the province.

24 Albrecht Noth, "Zum Verhhältnis von kalifaler Zentralgewalt und Provinsen un umayyadischer Zeit: die "Sulh"-“Anwa” Traditionen für Agypten und den Iraq," Die Welt des Islams 14 (1973): 150-162.

25 al-Ṭabarī, Tārīkh al-rusūl wa al-mulūk, ed. M.A. Ibrāhīm (Cairo: Dār al-Macārif, 1967), 614615 ; cf. as well the contribution of Michele Campopiano in this volume.

26 Hugh Kennedy, "Elite Income in the Early Islamic State," in The Byzantine and Early Islamic Near-East: Elites Old and New, eds. John Haldon and Lawrence I. Conrad (Princeton: Darwin Press, 2004), 13-14.

27 Abū Yūsuf, Kitāa al-kharāj, ed. M.I. al-Bannā (Cairo: Dār al-I'tisam, 1981), 69.

28 Ibn Sallām, Kitāb al-amwāl, ed. M.Kh. Harrās (Cairo: Dār al-Salām, 1969), 152-153. 
of the pre-conquest owners and kept as entirely liable to kharāj. ${ }^{29}$ The jund of Egypt would have then relied exclusively on salaries paid to them and their families because of their participation in the conquest (in cash: 'at $\bar{a}$ and in kind: rizq). This decision appears in the sources in the form of a direct prohibition, from the caliph 'Umar I to the jund, forbidding them from settling in the Egyptian countryside. ${ }^{30}$ Demands for allocations of land in Egypt by the conquest army were then refused according to Ibn 'Abd al-Hakam who specifies that settlers were prohibited to "farm themselves (zara'a) or have their land farm by tenants $\left(z \bar{a} r a^{c} a\right)^{\prime \prime}{ }^{31}$ In the words of al-Maqrīzì (d. 845/1442), around six centuries later, it halted the settlement of Arab tribes in the Egyptian countryside, a phenomenon that would only start after the first hijrī century $(710 \mathrm{~s} / 720 s){ }^{32}$

However, as S. Bouderbala has shown in his contribution to this volume, Ibn 'Abd al-Hakam also refers to the settlement of the tribe of Mudlij in the western Delta before the beginning of the first fitna $(35 / 656)$. He also attributes the granting of the first qațīa in Egypt precisely to 'Umar I. ${ }^{33}$ The Egyptian author even dedicates a whole chapter to the allocations of those grants. ${ }^{34}$ Most were located in Fusțât and they were urban and not rural qațía. Only one report refers to a rural qațīa given to a mawlā known as Ibn Sandar. ${ }^{35}$ However, historical accounts concerning this individual are very poor, and even his belonging to the jund of Egypt is in doubt, as pointed out by Ibn Yūnus. ${ }^{36}$ 'Umar I would have granted (aqta'a) 1000 faddāns north of Fusțāt to him and this land would have been later bought from his heirs by the Umayyad financial governor alAșbag (in office 86/705). What we witness here is surely another attempt to credit 'Umar I with the foundation of the early Islamic state and social structures, here with the granting of the first qați $a$ in Egypt, which seems to have little historical grounding. ${ }^{37}$

29 Morimoto, "Land Tenure," 111-115 and "Muslim Controversies," 100-101.

30 Ibn 'Abd al-Ḥakam, Futūḥ, 64-72, 82-84, 87-9o; al-Balādhurī, Futūḥ al-buldān, ed. M.J. de Goeje (Leiden: Brill, 1866), 214.

31 Ibn 'Abd al-Hakam, Futūh, 162.

32 al-Maqrīzī, al-Mawā $i z$ wa al- 'it tibār fì dhikr al-khițaț wa al-Āthār, ed. A.F. Sayyid (London: al-Furqān, 2002-2004), 4:49.

33 Ibn 'Abd al-Ḥakam, Futūh, 137.

34 Ibn 'Abd al-Hakam, 132-139 (dhikr al-qațāic').

35 Morimoto mistakenly wrote Ibn Sandal: "Land Tenure," 114.

36 Ibn Yūnus, Tārīkh, 1:470.

37 On the foundation of the early Islamic state being systematically attributed to 'Umar I, cf. Tayeb El-Hibri, Parable and Politics in Early Islamic History: The Rashidun Caliphs (New York: Columbia University Press, 2010), 78. 
Ibn 'Abd al-Hakam then transmits a number of reports on land grants in relation to the first Umayyad caliph Mu'āwiya (r. 38/659-6o/68o). ${ }^{38}$ The governor 'Uqba b. 'Āmir (in office 44/665-47/668) apparently requested from him a portion of land in a village, the location of which remains unknown. ${ }^{39}$ Two different versions of this passage are given. The first one describes this land only for its quality (ard șāliha) and the second one by its type of crop (baqĩan fi qarya - an orchard in a village). ${ }^{40}$ There is no indication in the narrative that this grant was refused to him. In the same work, in the chapter concerning the first settlements around the mosque of 'Amr in Fustạt, other allocations given (aqtáa $a$ by Mu'âwiya are mentioned. ${ }^{41}$ It is said that he tried to grant his son, the future caliph Yazīd I (r. 6o/68o-64/683), a village in the Fayyum, but that the people (al-nās, that is the people of the jund), complained asking for the return of this village to kharāj land, and it was kept as such. ${ }^{42}$

It is only in the beginning of the eighth century that we hear again about new Arab settlement in the countryside. At the suggestion of the financial director of Egypt, 'Ubayd Allāh b. al-Ḥabhāa (in office 105/724-116/734), the caliph Hishām (r. 105/724-125/743) agreed in 109/727 to install members of the tribe of Qays from Syria in the eastern Delta. This event is recorded in Ibn 'Abd al-Hakam's History of the Conquest, in the History of the Patriarchs of Alexandria, and is especially detailed in al-Kindi's Book of the Governors. ${ }^{43}$ The land on which they settled is described as "districts in which there were no inhabitants". ${ }^{4}$ The absence of previous settlement ensured the continuation of kharāj payments. This report also gives evidence for land reclamation as it is said that this land was used for their animals to graze, a common first step that eventually allows land to be brought back into cultivation. ${ }^{45}$

38 Cf. also: Morimoto, "Land Tenure," 114-115.

39 Ibn 'Abd al-Ḥakam, Futūh, 85-86.

40 "Yas'aluhu'ardanyustarfiqu fih à 'inda qaryat 'Uqba" (he requested land for which he would support him in the village of 'Uqba); "yas'aluhu baqĩan fi qarya yabnì fihi manāzil wa masākin" (he requested an orchard in a village in which he would build warehouses and houses): Ibn 'Abd al-Ḥakam, Futūh, 85.

"dhikr min ikhtaț̣a hawa al-masjid al-jāma'ma'a 'Amr b. al-'Aș̣," Ibn 'Abd al-Ḥakam, Futūḥ, 98-128.

42 Ibn 'Abd al-Ḥakam, 101.

43 Ibn 'Abd al-Hakam, 143; al-Kindī, Wulät, 76-77; History of the Patriarchs of the Coptic church of Alexandria, ed. and trans. B. Evetts, Patrologia Orientalis 5 (1910), 101.

44 "Kür laysa fìhā ahạd": al- Kindī, Wulāt, 76.

45 I would like to thank P. Verkinderen for pointing this out to me. On the implementation of the tribe of Qays in the Delta cf. Yaacov Lev, "Coptic Rebellions and the Islamization of Medieval Egypt (eighth-tenth Century): Medieval and Modern Perceptions," Jerusalem Studies in Arabic and Islam 39 (2012): 308-312. 
The interesting thing to note is that all those traditions identify the caliph as the only authority through which land grants could be obtained in the Umayyad period. After that both Ibn 'Abd al-Hakam and al-Kindī do not mention any land grants, which might indicate that the allocation of land was not a problem or a privilege anymore. Another remarkable fact is that although Iraqi sources written in the Abbasid period take a lot of interest in what became of Sasanian imperial estates, there is no mention of similar Byzantine possessions in Egypt. ${ }^{46}$

Both K. Morimoto and P. Sijpesteijn have shown, on the basis of papyrological evidence, the absence of Muslim settlement south of Fusțāt until the first decades of the eighth century, confirming the chronology provided above by Maqrīzī for part of the province. ${ }^{47}$ It is also clear that some members of the jund of Egypt had estates in other provinces of the empire. The most famous example is the conqueror and first governor of Egypt 'Amr b. al-Ās (in office 20/641$25 / 646$ then $38 / 659-43 / 664$ ) and his long lasting familial estates in Palestine. ${ }^{48}$ Another less known example is an unfortunately undated register of Aphrodito mentioning workers sent to the estate of the governor of Egypt in Damascus at the beginning of the eighth century. ${ }^{49}$ Among other evidence, these two examples contribute to reveal the geo-strategic interest of the early Islamic community settled in Egypt. J.-Cl. Garcin has argued that the main strategic routes in which the province of Egypt played a part during that period were orientated east and west following the progression of the conquest and connections to the imperial centers in Damascus and then in Bagdad until the rise of the Fatimids. In that sense, until the tenth century, Lower Egypt and its connection to the Middle East and the Mediterranean remained the main point of focus of the Islamic literary and political elite. ${ }^{50}$ Along those lines, there did not seem to be

46 Morimoto, "Land Tenure," 114. Ibn 'Abd al-Hakam only mentions that some members of jund settled in Alexandria in houses abandoned by the Byzantine elite: Bouderbala, "Ğund Miṣr," 142-143.

47 Morimoto's investigation of the registers of Aphrodito revealed the absence of landlords or tenants with Arab Muslim names: "Land Tenure," 117-120. Sijpesteijn, "Landholding Patterns," 123-124.

48 Michael Lecker, "The Estates of 'Amr b. al-Āṣ in Palestine," Bulletin of the School of Oriental and African Studies 52, no. 1 (1989): 24-37.

49 P.Lond. IV 1414, 81, 151 (Aphrodito, first half of the eighth century). The dated documents of Aphrodito originate from between 703 and the 720 , covering the following governorates: 'Abd al-'Azīz b. Marwān (65/685-85/705), 'Abd Allāh b. 'Abd al-Malik (85/705-9o/709), Qurra b. Sharīk (9o/709-96/714), 'Abd al-Malik b. Rifāa (96/714-99/717), Ayyūb b. Shurahil (99/717-101/719) and Bishr b. Șafwān (101/719-102/720).

$5^{\circ}$ Jean-Claude Garcin, "Pour un recours à l' histoire de l' espace vécu dans l'étude de l'Égypte arabe," Annales: Economie, Société, Civilisation 35, no. 3/4 (1980), repr. Espaces, pouvoirs et 
any strong incentive for the conquerors to demand land grants and to settle in the Nile valley and as is visible in the narrative sources, it is only in the Delta and the surroundings of Fustạt, including the Fayyum, that the conquest and Umayyad elite is known to have requested land grants. Then, 'Umar I's prohibition against settlement and farming in remote territories of the Nile valley, away from the main roads of the Empire and the concentration of elites, might not have been too burdensome for the conquest community in Fusțāt and should not be interpreted as effective isolation in the mișr.

This makes us question whether the interdiction of Umar I against the conquerors settling in the countryside should be seen as a literary topos, revealing how authors of the Abbasid period were making sense of settlement patterns following the conquest and in the Umayyad period. This situation might have been hard to explain when, in their time, Muslims held administrative posts throughout the countryside and had settled densely in the Nile valley. Moreover, as we will see from the evidence given in papyri, there are other reasons to doubt that the interest of the conquerors and the Umayyad elite was to leave the land in the hands of the conquered people and to collect kharäj from them.

Land and Estates in an Economy of Conquest and Empire Formation

Even if the absence of Muslim settlements in Upper Egypt before the early eighth century has been proven, papyri allow us to assess, before that time, the strong involvement of the conquerors and Sufyanid authorities $\left(38 / 659^{-}\right.$ $64 / 683$ ) in this region. From the time of the conquest on, we clearly see the expertise the conquerors developed in exploiting the Egyptian countryside through collection of taxes for their installation in the province, their sustenance and the construction of their new capital. ${ }^{51}$ Especially from the reign of

idéologies dans l'Egypte médiévale, Variorum Reprints (London: Ashgate, 1987), 436-451, 439-442.

$5^{1} \quad$ For the requisition of building material for the construction of Fusțât in the first years following the conquest, cf. Federico Morelli, Larchivio di Senouthios anystes e testi connessi: Lettere e documenti per la costruzione di una capitale (Berlin/New York: De Gruyter, 2010); on the involvement of the Umayyad authorities in the Sufyanid period, cf. Clive Foss, "Egypt Under Mu'āwiya, part I: Flavius Papas and Upper Egypt," Bulletin of the School of Oriental and African Studies 72, no. 1 (2009): 1-24; Clive Foss, "Egypt Under Mu'āwiya, part II: Middle Egypt, Fusțāt and Alexandria," Bulletin of the School of Oriental and African Studies 72, no. 2 (2009): 259-278; Marie Legendre, "Neither Byzantine nor Islamic? The 
Mu'âwiya, the collection of taxes served the great imperial projects of the Umayyad caliphs: military campaigns, especially the fleet, developing further into the Marwanid period (64/683-132/750) for great building projects in Egypt and in Syria, for all of which food products, building material and forced labor was provided. ${ }^{2}$

As described by H.I. Bell on the basis of the documents of Aphrodito, until the first decades of the eighth century, the fiscal system clearly appears to be organized around three blocks of taxes: regular public taxes, extraordinary imposts and corvée labor. All three blocks were paid by a number of taxes in cash and/or in kind. Regular public taxes were the gold and corn tax, extraordinary imposts could be paid either in cash or in kind according to what was needed by the authorities, and finally men could be supplied for the corvée or money could be sent to pay for their wage and maintenance. ${ }^{53}$ This division between taxes paid in money and taxes paid in kind is clearly visible in the Greek documents but also in the development of the fiscal vocabulary in Arabic documents. Regular imposts are found under jizya for taxes paid in money, dariba for the corn tax without specific reference to land-tax and poll-tax for instance. A third category called $a b w \bar{a} b$ referred to supplementary taxes the Umayyads made a great use of, covering their supplementary requisitions in money, foodstuff, building materials and work force. ${ }^{54}$ Those categories reveal the interest the early conquerors and Umayyad state developed in the Egyptian countryside: collecting taxes in kind and in money to benefit their continuous conquest and the building of their empire.

If we look at how those taxes in kind and in money were collected it is clear that they came from both imposts on land and on people - for instance, the regular gold tax or jizya was definitely collected from poll and land taxes among others, ${ }^{55}$ but the meaning of this term in the Umayyad period is clearly 'moneytax'. In addition to the absence of a specific term for land-tax (or poll-tax) in the earliest Arabic documents from Egypt, the absence of the term kharäj is also notable. It does not appear in any papyri published until now prior to the

Duke of the Thebaid and the Formation of the Umayyad State," Historical Research 89, no. 243 (2016): $3^{-18 .}$

52 Foss, "Flavius Papas," 18-22; Harold I. Bell, "The Administration of Egypt under the Ummayad Khalifs," Byzantinische Zeitschrift 28 (1928): 278-286.

53 Bell, 282-284.

54 For Greek and Coptic documents see: Harold I. Bell, Greek Papyri in the British Museum, Catalogue with Texts Iv, The Aphrodito Papyri (London: British Museum, 1910), xxv-xxxii, for Arabic documents: Geoffrey Khan, Arabic Documents from Early Islamic Khurasan (London: The Nour Foundation, 2007), 42-48. 
Abbasid takeover. ${ }^{56}$ These differences in the usage of Arabic terms in various periods can be misleading especially when later authors employ those words to talk about eras when they were not in use.

As for actual evidence of landowning and estates between the conquest and the middle of the Umayyad period, the documents of the pagarchy of Apollonos Ano/Edfu in the time of Mu'āwiya give evidence for estates in the hands of the Christian administrative elites such as the pagarch. ${ }^{57}$ Moreover, as noted by $\mathrm{K}$. Morimoto, the early eighth-century registers of Aphrodito mostly mention small peasant landholdings, and only a handful of large estates, which is very different from the situation in the sixth-century corpus from the same village. ${ }^{58}$ This might reveal the progressive loss of an economic power base by local elites still involved in the administration, who could no longer manage large scale estates which were therefore progressively fragmented. ${ }^{59}$ Such a suggestion would need to be further investigated but, it would be interesting to question if this has any link with the high fiscal demand of the Umayyad state. The loss of administrative power by the local elite is also visible in the early eighth century as from his time on local pagarchs are all replaced by administrators bearing Muslim names. ${ }^{60}$ In parallel to that, and as noted by P. Sijpesteijn, we find one mention of a caliphal estate in the Fayyum in a Greek papyrus dating from 69970o. This contract for wine production was drawn up for the benefit of the estate of the caliph, called protosymbulos in Greek - the caliph being at that time 'Abd al-Malik b. Marwān (r. 65/685-86/705) ${ }^{61}$ This is a rather thin piece of contemporary evidence for caliphal estates for the whole Umayyad period to which only one more can be added: an orchad of the caliph mentioned in a papyrus from Aphrodito when Sulayman b. 'Abd al-Malik was caliph. ${ }^{62}$ This shows, like the later Islamic narratives, that the caliph was involved and benefited from land allocations in Egypt.

\section{$4 \quad$ Questions on the Development of a Muslim Landowning Class}

A new context is visible in papyri at the turn of the eighth century. One might find the first administrators of a new profile, bearing Muslim names, in the very

$56 \quad$ Khan, Khurasan, 43, n. 88.

57 P.Apoll. 63 (Edfu, 66os-68os); 64 (id.).

$5^{8}$ Morimoto, "Land Tenure," 117; Marthot, "Un village égyptien," 119-131.

59 A similar process is noted by J. Martinez for Spain in his contribution to this volume.

6o Legendre, "Neither Byzantine," 15.

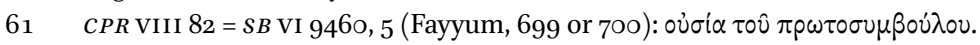

62 P. Lond. IV 1434, 33 (Aphrodito, 716). 
last decades of the seventh century. ${ }^{63}$ In any case, by the second decade of the eighth century, wherever the local city officials are known in the valley, they bear Muslim names. We do get a strong sense that the population of the Egyptian rural areas was diversifying in that period, as individuals with Muslim names progressively appear locally and certainly became inhabitants of those regions. ${ }^{64}$ It is also at the same time, that a more differentiated fiscal vocabulary appears in Arabic papyri. Poll-tax and land tax begin to appear in Arabic tax receipts under the terms jizyat al-ra's and jizyat al-ard, their first attestation being in a tax demand note dated to $104 / 722 .{ }^{65}$

A number of pieces of evidence point to the subsequent development of a class of Muslim landowners. For one, uncertainty remains as to the sources of revenue of the new Muslim class of administrators appearing in the first decades of the eighth century in the valley, especially whether their revenue came from landholdings. We know very little about the life of these officials as they only appear in a handful of documents. In the second quarter of the eighth century, some of them were appointed successively over several areas, pointing to the fact that they might not have had any local attachments. ${ }^{66} \mathrm{How}-$ ever, the documents related to one of the administrators of the Fayyum, 'Abd Allāh b. As‘ad (c. 730-750), published by P. Sijpesteijn, show that the officials of the late Umayyad and early Abbasid state were active in the trade of products not incompatible with landholdings (wheat and sheep). ${ }^{67}$ However, there is no information on the provenance of those products: were they coming from the rural property of those administrators? No evidence seems to confirm that so far. The first dated attestation of a landowner of Muslim name is also found in the first half of the eighth century. It is in an Arabic letter dated to $117 / 735$, also from the Fayyum, where a certain Abū al-Ḥārith is addressed by an individual

63 'Awf b. Nāfi' is found issuing fiscal documents in the Fayyum in the 68os or 69os and 'Abd al-Raḥmān b. Abī 'Awf and 'Abd al-Raḥmān b. Shurayḥ in the region of Heracleopolis/Ihnās in 677 or 707: Nikolaos Gonis, and Federico Morelli, "Two Entagia in Search of an Author," Bulletin of the American Society of Papyrologists 39 (2002): 21-25 = SB XVIII 13771.

64 On the difficulties of understanding the origin and denomination of individuals only on the basis of the names mentioned in papyri, cf. Marie Legendre, "Perméabilité linguistique et anthroponymique entre copte et arabe: exemple de comptes en caractères coptes du Fayoum fatimide, en annexe: répertoire des anthroponymes arabes attestés dans les documents coptes," in Coptica Argentoratensia, Conférences et documents de la $3^{e}$ université d'été en papyrologie copte, Bibliothèque d'Etude Coptes, eds. Anne Boud'hors et al. (De Boccard, Paris, 2014), 325-440.

65 This document is housed in the collection of the University of Geneva, P.Gen. inv. 713, and will be published by Khaled Younes.

66 Sijpesteijn, Shaping a Muslim State, 205-206.

67 Sijpesteijn, 364-368. 
who seems to be his employer, an estate holder whose name is not preserved. ${ }^{68}$ Notably, this is only a few years after Islamic and Christian narratives report the settlement of the tribe of Qays in the Nile Delta $(109 / 727){ }^{69}$

More information is found in both literary and documentary sources about the social context of the first half of the eighth century. The reign of the caliph 'Umar II (r. 99-101/717-720) in particular is known in later narratives for the fiscal rescript he issued concerning the status of Muslims, converts and non-Muslims. ${ }^{70}$ By that time the categories of conquered and conquerors had blurred significantly as the conquered had been recruited in the administration and especially in the army and the heirs of the conquerors were less and less involved in either of these activities. ${ }^{71}$ The development of a class of Muslim subjects of mixed background became a tricky problem for the Umayyad authorities, as traditionally all Muslims were part of the state elite whose families had participated in the conquest and as such were rewarded with salaries through the dīwann system. This is precisely the subject of the rescript issued by 'Umar II. As Muslims became subjects of the Umayyad state, what kind of taxes did they have to pay? As they settled in the countryside as subjects, and not thanks to a caliphal land grant, should they be subject to the same taxes as nonMuslims? It is precisely to the late seventh and early eighth century that A. Noth dated the rise of controversies among jurists on the nature of the conquest, which asserted that the conquered land should remain in the hands of the conquered using an overall fiscal framework distinguishing taxes paid by Muslims from those of non-Muslims. Those discussions do appear to fit with the context of the beginning of the eighth century in Egypt, as those debates could not have arisen before Muslims became a taxable category for the Umayyad state. ${ }^{72}$ Still, further research needs to be done to test this chronology for other provinces of the empire.

68 Petra M. Sijpesteijn, "Travel and Trade on the River," in Papyrology and the History of Early Islamic Egypt, eds. Lennart Sundelin and Petra M. Sijpesteijn (Leiden: Brill, 2004), 115-152.

69 See above n. 45 .

70 Azeddine Guessous, "Le rescrit fiscal de 'Umar b. 'Abd al-Azīz: une nouvelle interprétation," Der Islam 73 (1996): 113-137.

71 On the massive recruitment of mawāli in the Egyptian army at the beginning of the eighth century, cf. Sobhi Bouderbala, "Les mawālī à Fusțāt aux deux premiers siècles de l' Islam et leur intégration sociale," in Le processus d'islamisation en Sicile et en Méditerranée centrale, ed. Annliese Nef (Rome/Paris: Ecole Française de Rome, 2014), 141-151.

72 As pointed out by Luke Yarbrough in his contribution to this volume concerning hadiths which entered circulation in the context of debates on the issues they discuss, and not prior to these debates. 
It is also in this context that we can make sense of the appearance of a specific term for the land tax, as for the poll-tax, in Arabic fiscal documents. As the social and religious status of the subjects of the Islamic state was not as uniform as before, there was a necessity for a clear view of who was paying which taxes. As noted by G. Frantz-Murphy, the appearance of individual liability (as opposed to communal - village or quarter) in the first decades of the eighth century is another of the main features of the later Umayyad fiscal system. It also points to the fact that the state needed to access the individual status of tax-payers in order to assess tax rates..$^{73}$ The finance director of Egypt of the time, 'Ubayd Allāh b. al-Habhāāb, mentioned above in relation to the settlement of the tribe of Qays, is also known to have executed a census in the years 105/724-107/725. This measure is documented both in literary and documentary evidence and it appears to have been indispensable for a large scale administrative and fiscal assessment of the landowning population of Egypt. ${ }^{74}$ This census was, according to literary sources, followed by an increase of the land tax that set off a number of revolts from both Muslims and non-Muslims. As subjects of the Islamic state these two groups were now equally able to negotiate their status as landowners in the Egyptian countryside. ${ }^{75}$ Let us note again that the term kharäj was not in use in Egypt in that period or at all until the end of the Umayyad era and the same is noticeable for the term 'ushr, the tithe paid by non-Muslims according to literary texts. ${ }^{76}$ At the time of the Abbasid takeover, P. Sijpesteijn indicates that documents of 'Abd Allāh b. As'ad (73os75 os) still revealed the payment of different taxes paid in money 'often lumped together' under the term jizya. ${ }^{77}$

73 Frantz-Murphy, "Economics of State Formation," 105.

74 Nabia Abbott, "A New Papyrus and a Review of the Administration of 'Ubaid Allāh b. alḤabhāā," in Arabic and Islamic Studies in Honor of Hamilton A.R. Gibb, ed. George Makdisi (Leiden: Brill, 1965), 21-35.

75 Revolts break out in the Egyptian countryside as early as the late seventh century: Harold I. Bell, "Two Official Letters of the Arab Period," Journal of Egyptian Archaeology 12, no. 3/4 (1926): 271. Lev, "Coptic Rebellions," 303-344.

76 Cf. below $n$. 88 for the first attestation of the term 'ushr. Jurists indicate that 'ushr payment were completed through the șadaqa or zaqat which are found in documents: Sijpesteijn, Shaping a Muslim State, 181-198.

Sijpesteijn, 173. 
The picture we get, at the beginning of the Abbasid period, is that the Egyptian valley was administered, in the cities but not necessarily in the villages, by officials with Muslim names and landowners of the same profile are also visible but attested only in very small numbers. It is also clear that local Muslim communities in the valley remained a numerical minority for several centuries to come. ${ }^{78}$

Throughout the eighth century, only a few examples of lands in the hands of Muslim owners are traceable in the papyri but this number rises exponentially towards the end of the century. ${ }^{79}$ Most of those documents are unrelated and we cannot reconstruct the provenance and social status of these early Muslim landowners, their profession, the size of their land or estates and how they acquired it. A study of the continuity of names in land leases and tax receipts in the corpus put together by G. Frantz Murphy is not realistic either. The available corpus comes from diverse places and individual documents rarely tell us about the same land or landowner twice. Moreover, they do not identify landholdings very precisely. The individual liable for the taxes of these lands are, rather, mentioned with the village where the land is found but no information would allow us to differentiate various taxable portions in one village.

As for the difference in the fiscal system applied to Muslim landowners or tenants in comparison with their Christian counterparts, it is hard to reconstruct in the absence of tax registers for a given village or town quarter. Only the registers of Aphrodito allowed H.I. Bell to reveal the fiscal system of the middle Umayyad period, but similar material has not been published yet for the Abbasid period. Only pieces of registers too fragmentary to reconstruct fiscal policies are available to us. ${ }^{80}$ One preliminary study of an account-book dating from after the Tulunid period (308/920-921) has been published by A. Grohmann who passed away without finalizing the full publication. ${ }^{81}$ In that sense, it is very difficult to judge if the rates given for the land tax between Christian and Muslim landowners in literary sources of the Abbasid period render anything of the everyday fiscal practice in the empire's countryside.

78 It appears that Christians remained the majority in the Egyptian countryside until the fourteenth century: Jean-Claude Garcin, "L'arabisation de l'Égypte," Monde Arabe: Migrations et Identités, Revue des Mondes Musulmans et de la Méditerranée 43 (1987): 132. Sijpesteijn, "Travel and Trade," 131-134.

8 o See for example: P.Cair.Arab. III 207, 208, IV 226, all ninth century.

81 This register is housed in Dar al-Kutub in Cairo: Adolf Grohmann, "New Discoveries in Arabic Papyri: An Arabic Tax-account Book (inv. no. 140o) Found in Umm el-Bureigât (Tebtynis) in 1916," Bulletin de l'Institut d'Égypte 32 (1949-1950): 169 . 
One remark must be made first on the appearance of the term kharäj in Egyptian papyri. The first attestation is found in a document of the Abbasid period dated to $150 / 767-768$. As shown by G. Frantz-Murphy, the term is part of an ensemble of administrative vocabulary brought by the Iraqi and Khurāsānī administrators serving the Abbasids. ${ }^{82}$ This might mean that kharäj was in use in Iraq before that date, but we lack evidence contemporary to the Umayyad period in that area to confirm that. However, an interesting corpus of parchment documents is available from early Abbasid Khurāsān (138/755-16o/777). What is visible in this corpus, as well as in Egyptian papyri, is that the term was used, in the beginning of the Abbasid period, to refer to 'taxes assessed in money', replacing, in Egypt, the term 'jizya'. G. Khan, the editor of the Arabic Khurāsānì documents, prefers to understand the term as 'land tax' although he admits that it could also refer to a combined assessment of poll-tax and landtax. ${ }^{83}$

The meaning of the term kharaj in that period is also well documented at the heart of the caliphal court in Iraq with Abū Yūsuf's (d. 182/798) Kitāb alKharāj, a fiscal treaty composed for the fifth Abbasid caliph Hārūn al-Rashīd (r. 170/786-193/809). This normative work is among the most common sources used by historians to look at the early Islamic fiscal system. However, it is clearly visible in the title that Abū Yūsuf uses the term kharaj in the sense of 'tax assessed in money'. Under the term kharāj he addresses the whole fiscal system: poll taxes, taxes on churches, etc. and not simply the land tax, that he even refers to as kharāj al-ard..$^{84}$

Egyptian documents of the early Abbasid period clearly employ kharāj to denote taxes in money, while darîba still refers to taxes paid in kind. An interesting development is visible however from the end of the eighth century on. As noted by G. Frantz-Murphy there is no trace of taxes in kind after $182 / 799 .{ }^{85}$ By the beginning of the ninth century, we then witness a shift through which the fiscal categories in use since the time of the conquest, taxes paid in money and taxes paid in kind, fall out of use to the benefit of a system entirely assessed in cash. Until the end of the Abbasid period in Egypt, the term kharäj kept the general meaning of taxes assessed in money. ${ }^{86} \mathrm{~A}$. Grohmann's note about

\footnotetext{
82 Frantz-Murphy, "Economics of State Formation," 106-114.

83 Khan, Khurasan, 33. Several documents of that corpus also refers to 'expenses of the land' (nafaqāt al-ard) together with other expenses such as for the couriers (al-barìd) of four officials (the future caliph al-Mahdī, the governor, captives and slaves): P.Khurasan 6 (mideighth century); 21 (158/774).

84 Abū Yūsuf, Kitāb al-kharāj, 22.

85 Frantz-Murphy, Agricultural leases, 33.

86 This observation is also true for legal sources, where kharāj does not always have the mean-
} 
the above-mentioned Tulunid register: "poll-tax, land-tax and pasture tax show the same issue of money, that is all taxes were comprehended in a fixed lumpsum", seems to confirm this idea. ${ }^{87}$ In parallel, several documents, such as some of those collected by G. Frantz-Murphy, are land-tax receipts where the term kharāj is being used. ${ }^{88}$ This indicates that kharāj kept a general (money-tax) and a technical (land-tax) meaning in papyri of the Abbasid period.

Finally, the payment of kharāj appeared to have little to do with Muslim or non-Muslim status, as the kharäj receipts were clearly issued to both categories. As for 'ushr, it appears only in a small number of papyri and G. Frantz-Murphy, who published one of those documents dated to 253/867, noted that kharäj and 'ushr are clearly interchangeable. ${ }^{89}$

\section{Terms Used for Estates}

In the light of the limitations of the Abbasid corpus, we will focus in the following pages on the different terms used in Arabic documents to refer to landholdings and how they relate to the information given in literary texts. We will also look into a small group of identifiable Muslim landowners in the Abbasid period: the Abbasid family and the Iraqi elite.

In fiscal documents, plots of land are not identified with any precision, their surface area for instance is rarely indicated. Different types of lands are, however, commonly referred in passing in all sorts of other documents (letters, lists, legal documents, etc.). The term that is found in most cases in Arabic papyri to refer to landholdings or estates is day'a (pl. diya $a^{c}$ ). Day'a is a general term for a private agricultural holding/property. ${ }^{90}$ As we will see below, the caliph is found as an owner of day'a in Egypt in the 'Abbasid period. The term also can have a wider geographical scope and can refer to small settlements. It is often found in registers or legal documents from the ninth/tenth century onwards, when the origin of one of the parties is specified as coming from such a day'a. It becomes a synonym for village as it is translated by most editors or could indicate a farm. ${ }^{91}$

\footnotetext{
ing of "land-tax:" Hossein M. Tabātabāci, Kharāj in Islamic Law (London: Anchor Press, $1983), 2-3$.

87 Grohmann, "Tax-account Book," 169.

88 For example: CPR XXI 39 (Fayyum, 213/828-829).

89 Gladys Frantz-Murphy, "Record of Tax from Imperial Estates in Ushmūnayn," in Wiener Papyri, als Festgabe zum 6o. Geburtstag von Hermann Harrauer, ed. Bernhard Palme (Vienna: Holzhausen, 2001), 246.

$90 \quad$ Kennedy, "Elite Income," 13-24.

91 E.g. P.Cair.Arab. 171 (al-Ashmūnayn?, 242/856-247/841); 184 (249/863-864).
} 
As noted above, the term that is used most regularly in Abbasid narratives to refer to Arab landholdings is qați a . As noted by H. Kennedy, what can be confusing is that, in theory, qați $a$ and day'a could refer to the same type of property, describing different aspects of the same land. Qați $a$ refers to land allocated as grant, according to literary sources only by the caliph, as opposed to a land that was bought or inherited. ${ }^{92}$ This technical term here defines the way the estate was given to its owner. As we have seen above, it can also refer to an urban quarter. ${ }^{93}$ Once this estate was granted to its owner, it became a private property and as such could be called day'a. I could locate only three documents related to qatăa $i$. The first one has been dated to the late second/eighth century. It is an account of cultivated land on the basis of a survey in the region of Ihnās and mentions a qațīa, the name of the owner being unfortunately fragmentary (only 'Abd remains) and a title: amir, which could refer to many different professions in the administration or the army. ${ }^{94}$ The second document is dated to șafar 270/August-September 883 and mentions the city of Assouan. It is fragmentary but appears to be a letter mentioning the payment of kharäj and jizya in the district of Assouan. In the middle of a fragmentary passage, it mentions the possessors of qata $\bar{a} i^{c}$ in the districts of the

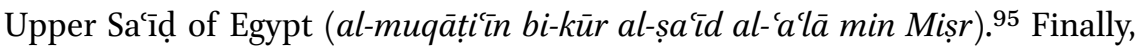
in an account of sheep entrusted to a shepherd of unknown provenance and dated to the third/ninth century, 3 o sheep are delivered to the workman of the qatĩ'a ('amil al-qațía). ${ }^{96}$ This evidence is rather thin to draw much of a conclusion concerning the functioning of qatăa $i^{\prime}$ in Egypt in the Abbasid period. Nonetheless, it is worth noting that they definitely need to be considered when writing the history of rural landholding in Egypt in the Abbasid period though it remains uncertain whether they were part of the Umayyad landscape. It can however be noted that, contrary to what narrative sources seem to suggest, they were not confined to the surroundings of Fustâat in the Abbasid period.

Another term found in papyri of the Abbasid period is usiyya, transcribing the Greek ovं $\sigma^{i} \alpha .{ }^{97}$ As we have seen, this term was used to refer to large estates in the Late Byzantine era. The Arabized form of this term is used for estates

\footnotetext{
92 Kennedy, "Elite Income," 13-14.

93 See the above n. 31 and Kennedy, "Elite Income," 14-18.

94 P.Khalili I 2 (Ihnās, late second/eighth century).

95 P.Hamb.Arab. I 14 (Assouan?, șafar 270/August-September 883).

$96 \quad$ P.Cair.Arab. vi 363, 6 (ninth century).

$97 \quad$ P.Cair.Arab. IV 2301 (ninth century); 271, 6 (273/886).
} 
in documents and continues to be in employed in al-Maqrīzìs text in the fifteenth century. ${ }^{98}$ In documents, it is a lot less common than day'a but is also used in some cases to refer to a small settlement. Finally, in legal documents, it is worth noting that contracts of sale of land simply refer to a plot of land as "ard" (land). ${ }^{99}$

\section{7 \\ Authority and Control in the Later Abbasid Period}

As showed by H. Kennedy on the basis of literary sources, it is clear that for other parts of the empire the principal owners of estates during the Abbasid period were the caliph, his family and administrative and military high officials. Egyptian papyri seem to render a similar image with the Abbasid elites appearing as the owners of $d i y \bar{a}^{c}$ in the ninth century, such as the vizier of the caliph al-Mutawakkil (r. 232/847-247/861) then appointed as financial director in Egypt: al-Fatḥ b. Khāqān (in office 242/856-247/861). ${ }^{100}$ A number of documents refer to the estates of al-sayyida, which according to Ibn Taghrī Birdī (d. 873/1469), an Egyptian author of the Mamluk period, referred to Shujā', the mother of the caliph al-Mutawakkil, originally a Khwārizmī slave-girl. However, as noted by G. Frantz-Murphy, Shujāe died in $249 / 863-864$ when documents mentioning al-sayyida appear in $238 / 852,253 / 867$ and $272 / 885-886$, and the epithet could also apply to the mothers of later caliphs. ${ }^{101}$ The second document is a record of taxes dated to $253 / 867$ where in addition to al-sayyida's estates, the day'a of Amājūr is mentioned at a time when he was still commander of weaponry (amìr al-siläh̆) in Baghdad. ${ }^{102}$ According to seven stelas found in the Basilica of al-Ashmūnayn, an estate also belonged in $258 / 872$ to the son of the late caliph al-Muntașir (r. 247/861-862). ${ }^{103}$

Those lands belonging to the close entourage of the caliph were certainly not occupied by their owners. They were virtual seats of authority mainly man-

98 al-Maqrīzī, Khițaț, 1:248.

99 E.g. P.Cair.Arab. I 53 (ninth century).

100 P.Cair.Arab. 171 (al-Ashmūnayn?, 242/856-247/841); Adolf Grohmann, Die Arabischen Papyri aus der Giessener Universitätsbibliothek (Giessen: Wilhelm Schmitz Verlag, 196o), 67.

101 CPR XXI 9 (Ihnās, 238/852); 21 (Ashmūn or Ihnās, 272/885-886); Frantz-Murphy, "Imperial Estates," 245 .

102 Frantz-Murphy, "Imperial Estates," 45-46.

103 Adolf Grohmann, "The Value of Arabic Papyri for the Study of the History of Medieval Egypt," Proceedings of the Egyptian Society of Historical Studies 1 (1951): 46. 
aged by appointees (wakil) also attested in papyri. ${ }^{104}$ The caliph al-Muntașir for instance was put in charge of the province of Egypt by the administration of Baghdad. In H. Kennedy's words, he was one of the 'super-governors' of the western Abbasid provinces. However, like many of them he is not known to have ever visited the province. ${ }^{105}$ Still, the political presence of the Abbasid elite circles in landholding also included lucrative advantages as chronicles convey the enormous revenue the caliph and the Abbasid elite extracted from their personal estates. ${ }^{106}$

However, narrative sources produced in Egypt by the end of the Abbasid period and beyond do not focus as much on elite landholding as they do, for instance, for Iraq. Papyri then give unparalleled evidence for this development. It is particularly interesting to note that those Abbasid estates mentioned in papyri do not seem to appear before the great Abbasid civil war (193/809218/833) during which Egypt was divided between the Arab leader 'Abd al-'Azīz al-Jarawi (d. second part of the ninth century) in the north and in the south al-Sarī b. al-Hakam (d. 251/865), the head of the $a b n \bar{a}^{3}$ in Egypt - the Abbasid Khurāsānī elite - while Andalusī contingents had taken control of Alexandria. The general 'Abd Allāh b. Țāhir (d. 230/844) sent by the Abbasids managed to unify the province again in $211 / 826$. This reunification was followed by strong measures of control by the caliph al-Ma'mūn (r. 189/813-218/833), marked by his visit in $217 / 832$. He and his successors entrusted the administration of the provinces to those 'super-governors' in the western provinces. The granting of estates to the family of those officials, members of the Abbasid house or of the Turkish military appear in this context as one more measure the Abbasids took to acquire a firmer grip on their provinces. As noted by $\mathrm{H}$. Kennedy this period seals the destruction of the early Islamic order for the Arab families who had settled in Fusțāt in the years of the conquest. The Abbasid authorities even initiated in Egypt a land grant system for the ruling elite that appeared to have been alien to early Arab settlers. ${ }^{107}$

\footnotetext{
104 E.g. P.Cair.Arab. 289 (ninth century); Abraham L. Udovitch, Partnership and Profit in Medieval Islam (Princeton: Princeton University Press, 1970), 100.

105 Hugh Kennedy, "Egypt as a Province in the Islamic Caliphate, 641-868," in The Cambridge History of Egypt, vol. 1, Islamic Egypt: 640-1517, ed. Carl F. Petry (Cambridge: Cambridge University Press, 1998), 82.

106 The governor of Khurasan at the beginning of the second century A.H., Khālid b. 'Abd Allāh al-Qasrī would have made ten million dirhams per year out of his estates, the equivalent of the entire tax yield of a medium sized province. Kennedy, "Elite Income," 28.

107 Kennedy, "Egypt as a Province," 82-85.
} 
Thus he (al-Zubayr) took the fort by assault (Babylon), and the Muslims considered it legal to take all that was in it. 'Amr made its holders dhimmi$\mathrm{s}$, imposed the poll-tax on their person and kharāj on their land and communicated that to 'Umar ibn-al-Khațāa who endorsed it. ${ }^{108}$

Balādhurīs (d. 279/892) rapid description of the take-over of the fort of Babylon and its consequences simplified in a few lines decades, if not centuries, of the development of an Islamic fiscal system which took place in parallel with the adaptation to local conditions in each of the conquered provinces. His chapter

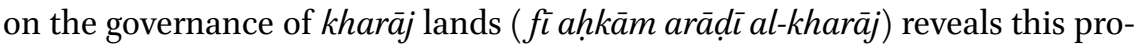
cess of codification of legal theories surrounding the land tax, the authorities he uses being prominent jurists of the eighth and early ninth centuries, such as Mālik (d. 179/798), Abū Hanīfa (d. 15o/767) and al-Shāfíī (d. 204/820). ${ }^{109}$ The theorization of this policy was developed from the second part of the Umayyad period on and especially in the Abbasid period by jurists. It presents a comprehensive treatment of the variety of lands that came to form the Dār al-Islām. The multifaceted situation that the Islamic conquest implied in terms of land use did not make its way in detail into the narratives that were composed from the end of the eighth century. However, documents from Egypt reveal the reality of fiscal practices and Muslim landholdings during this process of codification and the interest the successive elites developed in the land of Egypt.

It is clear that it is not until the end of the first Islamic century that substantial Muslim settlement occurred in the Egyptian valley. Until that date, the fiscal system applied there was arranged around taxes assessed in money and taxes assessed in kind both to be paid by non-Muslims. Those are the categories explicit in the earliest Arabic fiscal documents in the first part of the Umayyad period. After the second decade of the eighth century, administrators of Muslim names appear throughout the countryside, subsequently landholders of the same profile and the first documents mentioning in Arabic the payment of the land and poll-tax occur. However, the details of the late Umayyad and Abbasid fiscal system are not entirely accessible to us as no extant documentation is available from this period, in particular fiscal registers such as the ones from Aphrodito. Until such documentation gets published or a thorough inves-

\footnotetext{
108 Fa-fataḥa [al-Zubayr] al-ḥuṣn 'anwatan, wa-istabāḥa al-muslimūn mā fîhi wa-aqara Amr ahlahu 'alā innahum dhimma maw dư 'a layhim al-jizya fì riqābihim wa-l-kharāj fì ardīhim wa kataba bi-dhālika ilā Umar b. al-Khaț̣āb fa-ajāzahu: al-Balādhurī, Futūh al-buldān, 211. 109 al-Balādhurī, 447-448.
} 
tigation of the fragments of registers available to us is carried out, a lot of issues remain unclear. For instance, if and how taxes paid by Christians and Muslims differed, the nature of the first Muslim landowning communities, and, how the members of these communities acquired their lands.

As for the source material available to us, documentary and literary corpuses do correlate on a number of issues and events, such as the starting point of Muslim settlement in the Egyptian valley in al-Maqrīī’s fifteenth-century work which is confirmed by papyrological evidence. However, the explanation of that process appears quite differently in each corpus. Moreover, it seems that the most misleading part of this dialogue between literary and documentary sources is found in the vocabulary, especially the fiscal terms such as kharajj, jizya and 'ushr. As we have seen, it is clear that until the end of the Abbasid period, the differentiation of kharäj and 'ushr as taxes paid by non-Muslims and Muslims is absent from the Egyptian papyri. Kharāj kept a general meaning of 'tax assessed in money' and was used alongside with the technical meaning of 'land tax'. It is essential for further research to systematically contextualize the vocabulary used within the sources in which it is found, be it in Egypt or in other provinces of the early Islamic empire.

Finally, the only clearly identifiable group of Muslim landowners at present in the Abbasid countryside is the caliphal and military elite, who secured land revenues in Egypt in the aftermath of the great Abbasid civil war, a process that ultimately weakened Abbasid central power in the region. Other Muslim names appearing in relation to landholdings are mentioned in passing, but we know very little of their profile, their origin and how they acquired their land. This overview reveals the rare attempts at direct caliphal control in the Egyptian countryside through landholdings, corresponding to known moments of increased caliphal presence, under 'Abd al-Malik for instance or after the Abbasid fitna.

\section{Bibliography}

\section{Primary Sources}

Abū Yūsuf (d. 182/798). Kitāb al-kharāj. Edited by M.I. al-Bannā. Cairo: Dār al-I'tisam, 1981.

al-Balādhurī (d. 279/892). Futūh al-buldān. Edited by M.J. de Goeje. Leiden: Brill, 1866. Evetts, B., ed. and trans. History of the Patriarchs of the Coptic church of Alexandria. Patrologia Orientalis 5 (1910), 1-215.

Ibn 'Abd al-Ḥakam (d. 257/871). Futūh Mișr wa ahbāruhā. Edited by Ch. Torrey. New

Haven: Yale University Press, 1922. 
Ibn 'Abd al-Hakam (d. 214/829). Sīrat 'Umar b. 'Abd al-'Azīz 'alā mā rawāhu Mālik wa ashābuhu. 2nd edition. Edited by A. 'Ubayd. Cairo: Maktabat Wahba, 1954.

Ibn Mammātī (d. 6o6/1209). Kitāb Qawānīn al-Dawāwìn. Edited by A.S. Atiya. Cairo: Maktabat Matbūlī, 1943 .

Ibn Sallām (d. 224/838). Kitāb al-amwāl. Edited by M.Kh. Harrās. Cairo: Dār al-Salām, 1969.

Ibn Yūnus (d. 347/958). Tārīkh Ibn Yūnus al-Miṣrī. Edited by 'A. 'Abd al-Fattāḥ. 2 vols. Beyrouth: Dar al-Kutub al-ilmiyya, 2000.

al-Kindī (d. 350/969). Kitāb al-wulāt wa kitāb al-quḍāt. Edited by R. Guest. Leiden: Brill, 1912.

al-Maqrīzī (d. 845/1442). al-Mawā'iz wa al-'itibār fì dhikr al-khițaț wa al-Āthār. Edited by A.F. Sayyid. 4 vols. and index. London: al-Furqān, 2002-2004.

al-Ṭabarī (d. 310-923). Tārīkh al-rusūl wa al-mulūk. Edited by M.A. Ibrāhīm. Cairo: Dār al-Macārif, 1967 .

\section{Secondary Sources}

Abbott, Nabia. "A New Papyrus and a Review of the Administration of 'Ubaid Allāh b. al-Habhāāb." In Arabic and Islamic Studies in Honor of Hamilton A.R. Gibb, edited by George Makdisi, 21-35. Leiden: Brill, 1965.

Banaji, Jairus. Agrarian Change in Late Antiquity: Gold, Labour, and Aristocratic Dominance. Oxford: Oxford University Press, 2001 [reprinted in 2007].

Bell, Harold I. Greek Papyri in the British Museum, Catalogue with Texts IV, The Aphrodito Papyri. London: British Museum, 1910.

Bell, Harold I. “Two Official Letters of the Arab Period." Journal of Egyptian Archaeology 12, no. $3 / 4$ (1926): $265^{-281 .}$

Bell, Harold I. "The Administration of Egypt under the Ummayad Khalifs." Byzantinische Zeitschrift 28 (1928): 278-286.

Bouderbala, Sobhi. “Ǧund Mișr: étude de l' administration militaire dans l'Égypte des débuts de l' Islam (21/642-218/833)." PhD diss., Sorbonne University, 2008.

Bouderbala, Sobhi. "Les mawālì à Fusțāṭ aux deux premiers siècles de l'Islam et leur intégration sociale." In Le processus d'islamisation en Sicile et en Méditerranée centrale, edited by Annliese Nef, 141-151. Rome/Paris: Ecole Française de Rome, 2014.

Cahen, Claude. "L'évolution de l' iqtâ du $\mathrm{IX}^{\mathrm{e}}$ au XIII ${ }^{\mathrm{e}}$ siècle: contribution à une histoire comparée des sociétés médiévales." Annales: Économies, Sociétés, Civilisations 8, no. 1 (1953): $25^{-52 .}$

Cooper, Richard S. "Land Classification Terminology and the Assessment of the Kharāj Tax in Medieval Egypt." Journal of the Economic and Social History of the Orient 17 (1974): 91-102.

Delattre, Alain. Papyrus coptes et grecs du monastère d'apa Apollô de Baouît conservés 
aux Musées royaux d'Art et d'Histoire de Bruxelles. Bruxelles: Académie royale de Belgique, 2007.

Duri, 'Abd al-'Aziz. "The Origins of 'Iqta' in Islam." al-Abhath 22 (1969): 3-22.

El-Hibri, Tayeb. Parable and Politics in Early Islamic History: The Rashidun Caliphs. New York: Columbia University Press, 2010.

Foss, Clive. "Egypt under Mu'āwiya, part I: Flavius Papas and Upper Egypt." Bulletin of the School of Oriental and African Studies 72, no. 1 (2009): 1-24.

Foss, Clive. "Egypt under Mu'āwiya, part II: Middle Egypt, Fusțāṭ and Alexandria." Bulletin of the School of Oriental and African Studies 72, no. 2 (2009): 259-278.

Frantz-Murphy, Gladys. Arabic Agricultural Leases and Tax Receipts from Egypt, 148427 A.H./765-1035 A.D. Vienna: Hollinek, 2001.

Frantz-Murphy, Gladys. "Record of Tax from Imperial Estates in Ushmūnayn." In Wiener Papyri, als Festgabe zum 6o. Geburstag von Hermann Harrauer, edited by Bernhard Palme, 243-248. Vienna: Holzhausen, 2001.

Frantz-Murphy, Gladys. “The Economics of State Formation in Early Islamic Egypt.” In From al-Andalus to Khurasan: Documents from the Medieval Muslim World, edited by Petra Sijpesteijn, Lennart Sundelin, Sofia Torallas Tovar and Amalia Zomeño, 101-114. Leiden: Brill, 2007.

Garcin, Jean-Claude. "Pour un recours à l'histoire de l'espace vécu dans l'étude de l'Égypte arabe." Annales: Economie, Société, Civilisation 35, no. $3 / 4$ (1980). Reprinted in Espaces, pouvoirs et idéologies dans l'Egypte médiévale, 436-451. Variorum Reprints. London: Ashgate, 1987.

Garcin, Jean-Claude. “L' arabisation de l'Égypte." Monde Arabe: Migrations et Identités, Revues des Mondes Musulmans et de la Méditerranée 43 (1987): 130-137.

Garcin, Jean-Claude. Qūṣ: un centre musulman de la Haute-Égypte médiévale. Cairo: Institut Français d' archéologie orientale, 2005.

Gascou, Jean. "Les grands domaines, la cité et l'état en Égypte byzantine (recherches d'histoire agraire, fiscale et administrative)." Travaux et Mémoires 9 (1985): 1-9o. Reprinted in Fiscalité et Société en Égypte Byzantine, 125-213. Paris: Centre de recherche d' histoire et civilisation de Byzance, 2008.

Gaubert, Christian, and Jean-Michel Mouton. Hommes et villages du Fayyoum dans la documentation papyrologique arabe (Xe-XIe siècles). Paris: Droz, 2014.

Gonis, Nikolaos, and Federico Morelli. “Two Entagia in Search of an Author." Bulletin of the American Society of Papyrologists 39 (2002): 21-25.

Grohmann, Adolf. "New Discoveries in Arabic Papyri: An Arabic Tax-account Book (inv. no. 1400) Found in Umm el-Bureigât (Tebtynis) in 1916." Bulletin de l'Institut d'Égypte 32 (1949-1950): 159-170.

Grohmann, Adolf. "The Value of Arabic Papyri for the Study of the History of Medieval Egypt." Proceedings of the Egyptian Society of Historical Studies 1 (1951): 41-56.

Grohmann, Adolf. Die Arabischen Papyri aus der Giessener Universitätsbibliothek. Giessen: Wilhelm Schmitz Verlag, 196o. 
Guessous, Azeddine. “Le rescrit fiscal de 'Umar b. 'Abd al-'Azīz: une nouvelle interprétation." Der Islam 73 (1996): 113-137.

Heijer, Johannes den. "La conquête arabe vue par les historiens coptes." In Valeur et distance: identités et sociétés en Égypte, edited by Christian Décobert, 227-245. Paris: Maisonneuve et Larose, 2000.

Hickey, Todd M. "Aristocratic Landowning and the Economy of Byzantine Egypt." In Egypt in the Byzantine World 450-70o, edited by Roger E. Bagnall, 288-308. Cambridge: Cambridge University Press, 2007.

Kennedy, Hugh. "Egypt as a Province in the Islamic Caliphate, 641-868." In The Cambridge History of Egypt, vol. 1, Islamic Egypt: 640-1517, edited by Carl F. Petry, 62-85. Cambridge: Cambridge University Press, 1998.

Kennedy, Hugh. "Elite Income in the Early Islamic State." In The Byzantine and Early Islamic Near-East: Elites Old and New, edited by John Haldon and Lawrence I. Conrad, 13-28. Princeton: Darwin Press, 2004.

Khan, Geoffrey. Arabic Documents from Early Islamic Khurasan. London: The Nour Foundation, 2007.

Lecker, Michael. "The Estates of 'Amr b. al-'Āṣ in Palestine." Bulletin of the School of Oriental and African Studies 52, no. 1 (1989): 24-37.

Legendre, Marie. "Perméabilité linguistique et anthroponymique entre copte et arabe: exemple de comptes en caractères coptes du Fayoum fatimide, en annexe: répertoire des anthroponymes arabes attestés dans les documents coptes." In Coptica Argentoratensia, Conférences et documents de la $3{ }^{e}$ université d'été en papyrologie copte, Bibliothèque d'Etude Coptes, edited by Anne Boud'hors, Alain Delattre, Catherine Louis and Tonio Sebastian Richter, 325-440. De Boccard, Paris, 2014.

Legendre, Marie. "Neither Byzantine nor Islamic? The Duke of the Thebaid and the Formation of the Umayyad State." Historical Research 89, no. 243 (2016):3-18.

Lev, Yaacov. State and Society in Fatimid Egypt. Leiden: Brill, 1991.

Lev, Yaacov. "Coptic Rebellions and the Islamization of Medieval Egypt (eighth-tenth Century): Medieval and Modern Perceptions." Jerusalem Studies in Arabic and Islam 39 (2012): 303-344.

Løkkegaard, Frede. Islamic Taxation in the Classic Period, with Special Reference to Circumstances in Iraq. Copenhagen: Branner og Korch, $195^{\circ}$.

Marthot, Isabelle. “Un village égyptien et sa campagne: Étude de la microtoponymie du territoire d'Aphrodité ( $\mathrm{VI}^{\mathrm{e}}-\mathrm{VIII}{ }^{\mathrm{e}}$ s.)." PhD diss., École Pratique des Hautes Études, Paris, 2013 .

Marthot, Isabelle. "Monastic Estates in Transition from Byzantine to Islamic Egypt, Evidence from Aphrodito." (forthcoming)

Morelli, Federico. L'archivio di Senouthios anystes e testi connessi: lettere e documenti per la costruzione di una capitale. Berlin/New York: De Gruyter, 2010.

Morimoto, Koseï. "Land Tenure in Egypt during the Early Islamic Period." Orient 11 (1975): 109-153. 
Morimoto Koseï. "Muslim Controversies Regarding the Arab Conquest of Egypt." Orient 13 (1977): 89-105.

Morimoto, Koseï. The Fiscal Administration of Egypt in the Early Islamic Period. Kyoto: Dohosha, 1981.

Mouton, Jean-Michel. "Un village copte du Fayyoum au XI ${ }^{\mathrm{e}}$ siècle, d' après la découverte d' un lot d'archives." Comptes rendus de l'Académie des inscriptions et belles-lettres 146, no. 2 (2002): 447-458.

Noth, Albrecht. "Zum Verhhältnis von kalifaler Zentralgewalt und Provinsen un umayyadischer Zeit: die "Sulh"-“Anwa" Traditionen für Agypten und den Iraq." Die Welt des Islams 14 (1973): 150-162.

Rapoport, Youssef. Rural Economy and Tribal Society in Islamic Egypt: A Study of AlNabulusi's 'Villages of the Fayyum.' Turnhout: Brepols, 2018.

Richter, T. Sebastian. "Cultivation of Monastic Estates in Late Antique and Early Islamic Egypt: Some Evidence from Coptic Land Leases and Related Documents." In Monastic Estates in Late Antique and Early Islamic Egypt: Ostraca, Papyri, and Essays in Memory of Sarah Clackson, edited by Anne Boud'hors, James Clackson, Catherine Louis and Petra M. Sijpesteijn, 205-215. Cincinnati: American Society of Papyrologists, 2009.

Sato, Tsugitaka. State and Rural Society in Medieval Islam. Leiden: Brill, 1997.

Sijpesteijn, Petra M. "Profit Following Responsibility: A Leaf from the Records of a Third-Century Tax-Collecting Agent." Journal of Juristic Papyrology 31 (2001): 91-132.

Sijpesteijn, Petra M. "Travel and Trade on the River." In Papyrology and the History of Early Islamic Egypt, edited by Lennart Sundelin and Petra M. Sjpesteijn, $15^{-152}$. Leiden: Brill, 2004.

Sijpesteijn, Petra M. "Landholding Patterns in Early Islamic Egypt." Journal of Agrarian Change 9, no. 1 (2009): 120-133.

Sijpesteijn, Petra M. Shaping a Muslim State: The World of a Mid-Eighth-Century Egyptian Official. Oxford: Oxford University Press, 2013.

Tabātabāi, Hossein M. Kharāj in Islamic Law. London: Anchor Press, 1983.

Udovitch, Abraham L. Partnership and Profit in Medieval Islam. Princeton: Princeton University Press, 1970.

Verreth, Herbert. The Provenance of Egyptian Documents from the eighth Century Bc till the eighth Century AD. Köln/Leuven: Trismegistos Online Publications, 20og. http:// www.trismegistos.org/downloads/process.php?file=TOP_3.pdf.

Zuckerman, Constantin. Du village à l'Empire: autour du registre fiscal d'Aphroditô (525/526). Paris: Centre de recherche d'histoire et civilisation de Byzance, 2004. 